\title{
Thrombospondin-1 is a multifaceted player in tumor progression
}

\author{
Tingting Huang ${ }^{1}$, Li Sun ${ }^{1}$, Xianglin Yuan ${ }^{1}$ and Hong Qiu ${ }^{1}$ \\ ${ }^{1}$ Department of Oncology, Tongji Hospital, Tongji Medical College, Huazhong University of Science and Technology, Wuhan, Hubei, \\ PR China
}

Correspondence to: Hong Qiu, email: tjqiuhong@163.com

Keywords: thrombospondin-1, tumor progression, tumor angiogenesis, cancer cell behavior, tumor immunity

Received: March 16, 2017

Accepted: June 28, 2017

Published: July 11, 2017

Copyright: Huang et al. This is an open-access article distributed under the terms of the Creative Commons Attribution License 3.0 (CC BY 3.0), which permits unrestricted use, distribution, and reproduction in any medium, provided the original author and source are credited.

\section{ABSTRACT}

Thrombospondins are a family of extracellular matrix (ECM) proteins. Thrombospondin-1 (TSP1) was the first member to be identified and is a main player in tumor microenvironment. The diverse functions of TSP1 depend on the interactions between its structural domains and multiple cell surface molecules. TSP1 acts as an angiogenesis inhibitor by stimulating endothelial cell apoptosis, inhibiting endothelial cell migration and proliferation, and regulating vascular endothelial growth factor bioavailability and activity. In addition to angiogenesis modulation, TSP1 also affects tumor cell adhesion, invasion, migration, proliferation, apoptosis and tumor immunity. This review discusses the multifaceted and sometimes opposite effects of TSP1 on tumor progression depending on the molecular and cellular composition of the microenvironment. Clinical implications of TSP1-related compounds are also discussed.

\section{INTRODUCTION}

Extracellular matrix (ECM) is a complex threedimensional network of secreted proteins that is constantly remodeled due to the balance between synthesis, deposition and degradation [1]. The complex interplay between cells and ECM provides an environment that fosters cancer progression. Thrombospondins (TSPs) are a family of ECM proteins widely present in embryonic and adult tissues, which consist of five members: TSP1, TSP2, TSP3, TSP4, and TSP5 [2].

TSP1 was the first member to be identified, and is a main player in tumor microenvironment. Its role as an angiogenesis inhibitor was confirmed by numerous potential drugs against angiogenesis-driven diseases. Loss of TSP1 expression was regarded as an "angiogenic switch" from the non-angiogenic phenotype in tumor progression [3]. In addition to angiogenesis modulation, the effects of TSP1 on tumor progression are multifaceted and sometimes opposite depending on the molecular and cellular composition of the microenvironment [4]. Indeed, TSP1 regulates diverse processes such as adhesion, invasion, migration, proliferation, apoptosis, immunity response and treatment response by interacting with multiple ligands [4]. Consequently, strategies blindly targeting a specific function may result in severe adverse effects and the beneficial properties of the multifunctional
TSP1 may also be lost. Here, we will focus on TSP1 and its function in tumor progression. Clinical implications and further directions for targeting TSP1 are also discussed.

\section{The structure and function of TSP1}

Structural and functional domains of TSP1

TSP1 is a $450-\mathrm{kDa}$ homotrimeric glycoprotein. Mature polypeptide chains contain 1152 amino acids $(180 \mathrm{kDa})$, linked by disulfide bonds between cysteine 252 and 256 [5]. Each TSP1 subunit comprises of N- and C-terminal globular domains ( $\mathrm{N}$ and $\mathrm{G}$ domains) and a thin connecting strand (Figure 1) [6,7]. The $\mathrm{N}$ domains arise from the $\mathrm{N}$-terminal of the three polypeptidic segments. Each segment contains a heparin-binding domain (HBD) $[8,9]$. The affinity between TSP1 and heparin is used to purify TSP1 from platelets [10]. Adjacent to the N-terminal, there is a region that is homologous to procollagen. This domain is involved in the assembly of the protein into a trimer [2]. The role of this domain remains unknown but could be used to block the angiogenic process [11]. A motif repeated three times constitutes type I repeats (TSR1s) framed around six cysteinyl residues. Different active sequences in the TSR1s play different roles in tumor progression [12]. Type II repeats (TSR2s) constitute three motifs of 60 amino acids containing six cysteinyl residues as in TSR1. The precise 
role of the domains has not been reported in cell surface receptors interactions or cell growth regulation [2]. The seven type III repeats (TSR3s) are rich in aspartic residues and responsible for calcium binding. They interact with $\alpha v \beta 3$ and $\alpha I I \beta 3$ integrins in various cell types [13]. The $\mathrm{G}$ domain, also called cell-binding domain (CBD), is specific to the TSP family (TSP1-5) [14]. A peptide from the $\mathrm{G}$ domain has been proposed to stimulate platelet aggregation [15]. The cell binding peptide from the CBD is integrin-associated protein (IAP or CD47) [16].

\section{Interactions of TSP1with its receptors}

The diverse functions of TSP1 depend on the interactions between its structural domains and multiple cell surface molecules (Figure 1). The receptors for TSP1 include: low density lipoprotein receptor-related protein (LRP), proteoglycans and sulfatides, CD36, integrins, integrin-associated protein (IAP), and unidentified receptors for $\mathrm{G}$ domains [17]. Most domains could bind multiple receptors, indicating crosstalk between the receptor systems.

\section{TSP1 in tumor angiogenesis}

Angiogenesis, an important event in many diseases including cancer, is the process by which new blood vessels are formed from pre-existing vasculature [18]. The new blood vessel formation during tumor angiogenesis enhances tumor growth and provides an opportunity for cancer cells to metastasize [19]. Regulation of angiogenesis depends upon the balance between proangiogenic and antiangiogenic factors. There is controversy as to the exact biological function of TSP1 in angiogenesis. Although some studies suggest that TSP1 promotes neovascularisation [20], TSP1 is commonly recognised as an endogenous angiogenesis inhibitor.

\section{Domain-specific angiogenic activity}

The specific domains of TSP1 exert angiogenic activity. In the study by Tolsma et al. [11], a series of protease-generated fragments were tested by several assays that reflect angiogenic activity. They found that the majority of the antiangiogenic activity of TSP1 resides in the procollagen homology domain and TSR1s. Short peptides from these two domains could block the angiogenic process both in vivo and in vitro. Dawson et al. substituted one of three L-amino acids by their D-enantiomers in Mal II (a 19-residue peptide derived from TSR1s that was inactive in angiogenesis assay) [21]. Substituted peptides inhibited the migration of capillary endothelial cells, and showed potent antiangiogenic activity. DI-TSP, a modified version of Mal II, markedly suppressed the growth of endothelial cells in vitro and reduced microvessel density in vivo [22]. Another study showed that the second and third TSR1s but not the procollagen homology domain inhibited angiogenesis by chorioallantoic membrane angiogenesis and endothelial cell proliferation assays [23]. The expression of $4 \mathrm{~N} 1 \mathrm{~K}$ peptide derived from the $G$ domain significantly correlates with reduced tumor angiogenesis [24, 25]. Furthermore, the heparin binding 25kDa fragment of TSP1

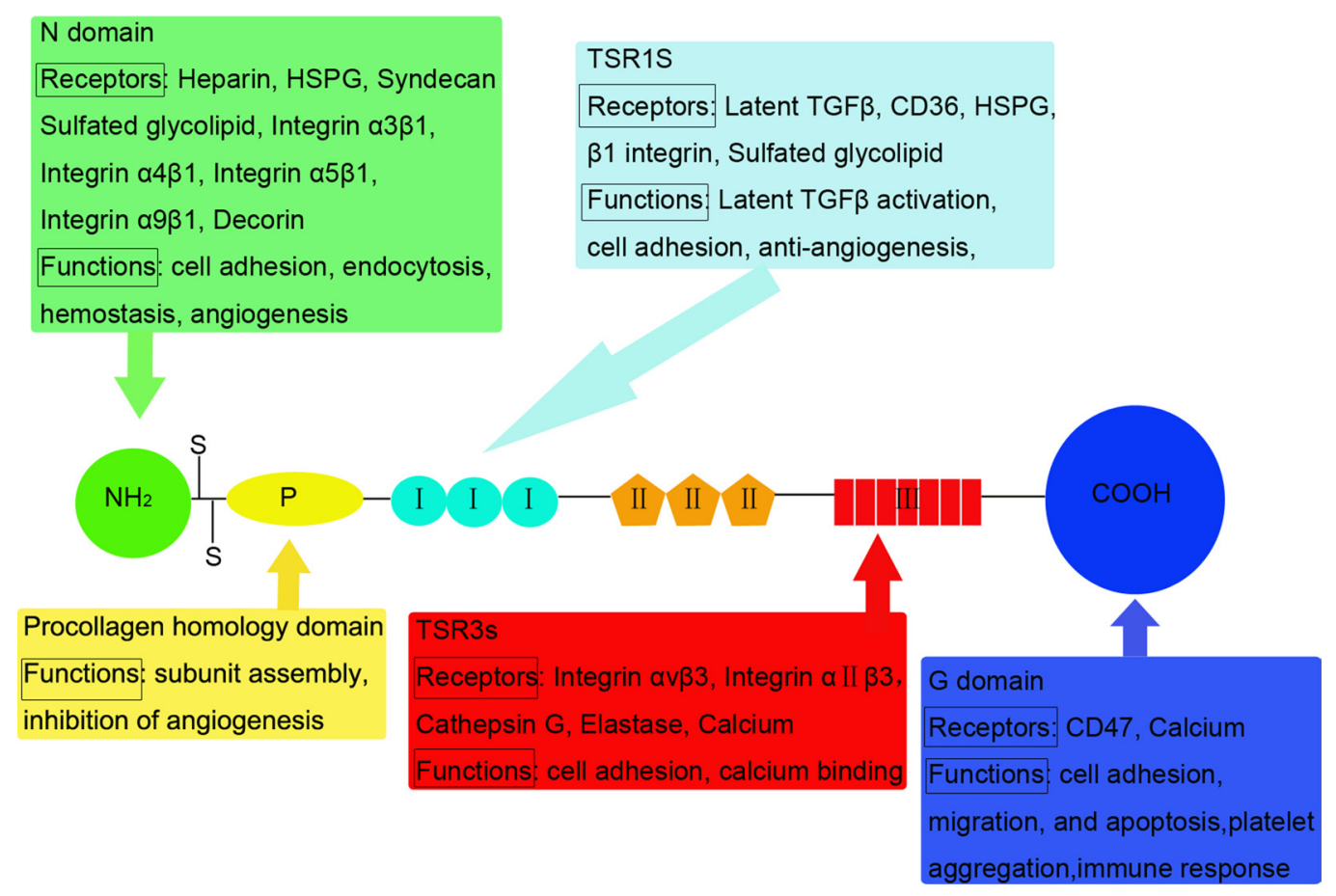

Figure 1: Structural and functional domains of TSP1: Mature polypeptide chains are linked by disulfide bonds. TSP1 monomer comprises of $\mathrm{N}$ and $\mathrm{G}$ domains and a thin connecting strand. Interactions between structural domains and multiple cell surface molecules determine the diverse functions of TSP1. Receptors and functions that have been identified for the various domains are listed below or above the motif. 
is responsible for the angiogenic activity. Conversely, the $140 \mathrm{kDa}$ fragment lacks angiogenic activity, and is a potent inhibitor of FGF2-induced angiogenesis [26]. Ferrari and colleagues reported that TSP18 (a recombinant $18 \mathrm{kDa}$ protein from the $\mathrm{N}$ domains of TSP1) accelerated tube formation of human umbilical vein endothelial cells (HUVECs) [27]. So the role of TSP1 in angiogenesis may rely on the tumor environment. The effect on angiogenesis will differ depending on which part of TSP1 is functional in a given setting.

\section{Stimulation of endothelial cell apoptosis}

TSP1 modulates the apoptosis of endothelial cells that are forming new vessels. Guo et al. demonstrated that peptides from TSR1s elicit endothelial apoptosis [28]. The mechanism for inducing apoptosis by TSP1 peptides did not require ceramide generation, which mediated apoptosis in many cell types due to various stimuli. The peptide-induced apoptosis was mediated by dephosphorylation, since tyrosine and serine-threonine phosphatase inhibitors significantly blocked bovine aortic endothelial cell apoptosis [28].

TSP1 binds numerous receptors, and CD36-TSP1 interaction is considered to be important as a negative regulator of angiogenesis [29]. HUVECs transfected with a CD36 expression vector had a slower growth rate than parental cells [30]. TSP1-induced apoptosis was sensitive to antibodies that neutralized TSP1 or blocked access of TSP1 to CD36. Treatment of endothelial cells with an antibody that activates CD36 induced apoptosis, verifying the role of CD36 in this response. Melanoma cells seeded in the lungs of nude mice seldom developed into tumors large enough to see with the naked eyes if the mice were systemically treated with TSP1. There was a considerable increase in the percentage of apoptotic endothelial cells in the TSP1-treated group as compared to the saline-treated group, mainly in the area of active neovascularization surrounding the tumor [31]. The CD36-dependent signaling pathways through which TSP1 mediates apoptosis was elucidated by the activation of CD36-p59 fyn caspase 3-p38MAPK cascade, c-Jun N-terminal kinases and Fas/Fas ligand [31-33].

TSP1 might also induce the apoptosis of endothelial cells by the lack of hemodynamic forces or irregular flow conditions [34, 35]. Hemodynamic forces were essential for the survival of vascular endothelial cells. The disturbance of laminar flow also induced apoptosis. These investigations showed that the apoptosis was induced by the autocrine loop of TSP1 and the $\alpha v \beta 3$ integrin/IAP complex in both cases. However, evidence demonstrated the administration of $\alpha v \beta 3$ antagonists led to the regression of angiogenic blood vessels [36]. This appeared to be inconsistent with the concept that TSP1, a ligand of $\alpha v \beta 3$, could induce apoptosis. At present, TSP1-directed receptor(s) which promotes endothelial cell survival during angiogenesis remains unclear.

\section{Inhibition of endothelial cell migration and proliferation}

Endothelial cell migration and proliferation are important for the formation of sprouting capillaries. CD36 is necessary for the inhibition of endothelial cell migration and tube formation by TSP1. Antibodies against CD36 prevented TSP1 from inhibiting migration. Large vessel endothelial cells that lacked CD36 became sensitive to TSP1-mediated inhibition of migration after CD36 transfection [30]. Cyclic TSP1 mimetics had higher potency in human microvascular endothelial cells (HMVECs) compared to HUVECs, which was likely due to the difference in expression of CD36 in HMVECs as compared to large vessel cells such as HUVECs [37]. While other researchers found TSR inhibited vascular endothelial growth factor (VEGF)-induced HUVEC migration via a CD36-independent pathway. TSR was unable to inhibit VEGF-induced migration using a $\beta 1$ integrins-activating antibody or by suppressing $\beta 1$ integrins, indicating that $\beta 1$ integrins was necessary for TSP1-mediated inhibition of migration. They raised that $\beta 1$ integrins could regulate cell migration via a PI3Kdependent, Akt-independent pathway [38]. These data are consistent with a prior observation that the TSP1 TSRs were pan-specific ligands for $\beta 1$ integrins [39]. Both CD36 and $\beta 1$ integrins may differentially contribute to TSP1-mediated migration inhibition depending on the microenvironment and the migration stimulus.

TSP1 induces growth arrest in endothelial cells by suppressing the cell cycle $[40,41]$. Yamauchi et al. suggested that TSP1 induces cell-cycle arrest through upregulation of p21 expression mediated by p53 [40]. The proliferation of HMVECs could be inhibited by the interaction of TSP1 with the very low density lipoprotein receptor (VLDLR). This process was not mediated by CD36 and TSRs [41]. Other mechanisms by which TSP1 inhibits endothelial cell proliferation need thorough exploration.

\section{Regulation of VEGF bioavailability and activity}

VEGF is a multifunctional cytokine that contributes to angiogenesis by both direct and indirect mechanisms. VEGF is overexpressed in a high percentage of malignant animal and human tumors [42]. The expression levels of VEGF and TSP1 are used to describe angiogenesis in different tumor samples. Upregulation of TSP1, together with downregulation of VEGF in cancer cells, might play a role in the hypovascularity of cholangiocarcinoma compared to hepatocellular carcinoma [43]. Increased VEGF-A and decreased TSP1 in carcinomas as compared to adenomas were associated with the malignant phenotype [44]. Microvessel count showed a significant positive correlation with the expression of VEGF and an inverse correlation with TSP1 in papillary thyroid carcinoma [45]. VEGF increased proliferation and migration of pituitary endothelial cells, while TSP1 suppressed these effects [46]. Breast tumors in a TSP1-rich environment could markedly 
increase the secretion of VEGF that counterbalance the inhibitory effect of TSP1 [47]. These findings indicate that the levels of VEGF and TSP1 are indicators of angiogenesis but do not explain if one regulates the expression of the other.

Mutation of the tumor suppressor gene p53 has been associated with the increase of VEGF expression and the decrease of TSP1 expression [48-50]. However, no association was found between p53 mutations and TSP1 in non-small cell lung carcinoma. While, a significant association was found between p53 mutations and high VEGF expression and neovascularization [51]. More patients are needed to prove an association between $\mathrm{p} 53$, VEGF and TSP1 expression in cancer.

\section{Impact of TSP1 on cancer cell behaviors}

\section{Adhesion}

Cell adhesion to ECM is a crucial step in tumor progression and metastasis. In 1987, TSP1 was first shown to function as a cell adhesive protein [52]. Thereafter, many studies have demonstrated that TSP1 mediates cellular adhesion of numerous cell types, regardless of species.

Integrins are a family of cell surface glycoproteins that play a major role in cell adhesion. The $\alpha 3 \beta 1$ integrin, with the cooperation of sulfated glycoconjugates and $\alpha 4 \beta 1$, was the domain integrin mediating adhesion of breast cancer cells to TSP1 [53]. Other studies showed that TSP1 favors direct MDA-MB-231 adhesion via $\alpha v \beta 3$ and $\alpha 6$ integrins $[54,55]$. The $\alpha v \beta 3$ integrin also mediated melanoma cell adhesion to TSP1 [56]. TSP1 was an adhesive protein for the human small cell lung carcinoma (SCLC) cell lines. The two classic SCLC cell lines, OH-1 and H128 attached only on substrates coated with TSP1. SCLC cells adhesion to TSP1 was mediated by interactions of TSP1 with both $\alpha 3 \beta 1$ integrin and sulfated glycolipids [57]. TSP1 could promote cell substrate adhesion to osteosarcoma cells through the $\alpha 4 \beta 1$ integrin. The adhesion to TSP1 was inhibited by antibodies against the $\alpha 4$ or $\beta 1$ subunit but not by antibodies against other integrins [58]. CD36 was the first nonintegrin receptor for TSP1 to be described. TSP1 overexpression up-regulated CD36, leading to enhanced adhesion of human cutaneous squamous cell carcinoma cells to TSP1 [59].

However, TSP1 has variable effects in tumor cell adhesion. TSP1 decreased tumor cell adhesion through upregulation of urokinase plasminogen activator receptor (uPAR)-controlled urokinase plasminogen activator (uPA) and plasmin activities [60]. These data suggest that TSP1 may have a dual role in tumor cell adhesion. The intrinsic proadhesive capacity of TSP1 plays a significant role in maintaining the cell-cell and cell-matrix interactions needed for local growth of tumors. When TSP1 overrides its intrinsic proadhesive effect, it promotes detachment of tumor cells from primary tumor, invasion of surrounding tissues, and metastasis.

\section{Invasion and migration}

Metastasis is a multistep event that allows tumor cells to invade through ECM and migrate to distant organs. The precise role of TSP1 in tumor invasion and migration remains controversial, with compelling evidence suggesting both stimulatory and inhibitory roles.

In the study by Pal et al., TSP1 enhanced the invasion and migration of oral squamous cell carcinoma cells and stimulated the expression of MMPs partly via the integrin signaling, which cooperatively facilitated cancer invasion [61]. The positive feedback between TSP1 and TGF $\beta$ provided a versatile system to rapidly build the tumor microenvironment [61-63]. Increased expression of TSP1 was associated with the invasive and metastatic phenotypes of melanoma and invasive ductal carcinoma of breast [64-66]. TSP1 was a potent stimulator of prostate tumor cell migration, and this effect required CD36, which also mediated TSP1 antiangiogenic activity [67]. Both oncogene and tumor- suppressor gene activation in cancer are associated with the regulation of TSP1 expression. PTEN or BRAF was involved in TSP1-induced invasion and migration of thyroid cancer cells [68, 69]. TSP1 regression by oncogenic Myc might be a critical determinant of metastatic phenotypes in medulloblastoma [70]. In our previous study, FGFR2-induced upregulated TSP1 was associated with the invasion and migration of human gastric cancer cells [71] .

An in vivo study of transgenic mice with breast cancer showed that tumors in TSP1-null mice grew faster than in wild-type mice. At 90 days of age, the number of metastatic lesions in lung was higher in the wild-type than TSP1-null mice [72]. TSP1 inhibited migration of clear cell renal carcinoma cells in response to different stimuli [73]. Esophageal squamous cell carcinoma patients with low expression of TSP1 were associated with worse progression-free survival. Furthermore, TSP1 inhibited the migration signaling in both cancer cells and surrounding endothelial cells in vitro and in vivo [74]. These results reinforce the pleiotropic nature of TSP1, which depends on the tumor microenvironment, and the presence of its different receptors may have different, even opposite, effects on cell behavior and biological process.

\section{Proliferation and apoptosis}

The first in vivo analysis of the impact of TSP1 in an intestinal carcinogenesis model at early stages of tumor initiation and development showed a decrease of TSP1 expression in adenomas, decreased tumor cell apoptosis, and its inverse relationship with more proliferative and vascularized intestine [75]. Similarly, azoxymethane/ dextran sodium sulfate induced tumors developed in TSP1- colons had higher proliferation index. TSP1 interacted with proteins implicated in proliferation, DNA repair, and transcriptional regulation such as protein arginine methyltransferase 6 [76]. Interestingly, proliferation only occurred when breast cancer cells were exposed to 
lower concentrations of TSP1, and increasing the TSP1 concentration attenuated cell proliferation [77]. In human prostate cancer and cutaneous squamous cell carcinoma, TSP1 did not directly affect proliferation and apoptosis of cancer cells $[59,78]$. TSP1 expression was an independent prognostic factor for clear cell renal cell carcinoma, and was strongly correlated with proliferation index [79]. In contrast, Miyata et al. were unable to show any significant correlation between TSP1 and various clinicopathological features or tumor size. The $4 \mathrm{~N} 1 \mathrm{~K}$ peptide from TSP1 exhibited significant association with microvessel density, apoptotic index and tumor size [24]. Differences in the populations, histological subtypes, and antibody used in these studies may explain the discrepancies.

\section{TSP1-mediated modulation of tumor immunity}

The ability of cancer cells to evade or escape the immune response is recognized as cancer hallmark, which provides a platform for treatments based on immunotherapies [80]. The first suggestion that TSP1 may influence the immune response of cancers came from the observation that TSP1 and its receptors played a role in monocyte-mediated killing of squamous carcinoma [81]. Several lines of evidence also suggested that TSP1 promoted M1 macrophage recruitment and cytotoxicity [82, 83]. Thus, avoiding this innate immune surveillance could provide a selective pressure to reduce TSP1 expression during tumor progression. Importantly, TSP1-primed monocytes upregulated TGF $\beta$ levels and successfully inhibited inflammation in the intestine. Since inflammatory bowel disease (IBD) is characterized by chronic inflammation in the intestinal tract and carcinogenesis is promoted by persistent chronic inflammation occurring in IBD, understanding the underlying mechanisms is essential in order to ameliorate inflammation and prevent colorectal cancer $[76,84]$. However, not all macrophages or monocytes residing in tumors are tumoricidal. Further work is needed to determine whether TSP1 can enhance or suppress tumoricidal activities of these cells.

The effect of TSP1 on early natural killer (NK) cells proliferation was related to activation of TGF $\beta$ because anti-TGF $\beta$ neutralizing antibody completely abrogated TSP1-mediated inhibition of early NK cell proliferation. However, active TGF $\beta$ added only at culture initiation increased late NK cell expansion similar to TSP1 [85]. These data suggest that besides TSP1/TGF $\beta$, additional factors are important for the regulation of $\mathrm{NK}$ cell proliferation.

TSP1 has been reported to induce regulatory $\mathrm{T}$ (Treg) cells. In human melanoma, anti-TSP1 mAb strongly inhibited $\mathrm{CD}^{+}$Treg induced by snail. Survival was significantly prolonged by the anti-TSP1 $\mathrm{mAb}$ in mice. When TGF $\beta \mathrm{mAb}$ was injected, no antitumor effect was observed. Since TSP1 is known to be a TGF $\beta$ activator, these phenomenon suggested that TSP1 would be a more potent effector molecule than TGF $\beta$ in the snail-induced immunosuppression [86].
The binding of TSP1 to CD47 controlled adaptive immunity via inhibiting T-cell activation and differentiation [87]. TSP1 ligation to CD47 further controlled immune responses by regulating maturation and trafficking of dendritic cells (DCs) [88-90]. Cutaneous administration of TSP1 shRNA or adoptive transfer of TSP1-deficient DCs produced anti-tumor effects by modulating the immune response in animal tumor models [91]. These TSP1/ CD47 pathways have pathophysiological consequences of immune challenges including in anti-tumor immunity.

Based on recent progress, the known and unknown mechanisms of TSP1 in tumor immunity are the major problems that limit the improvement of anti-tumor immune responses in cancer patients.

\section{Clinical implications}

Therapeutic strategies targeting TSP1 have been extensively reviewed $[4,92]$. Generally, three approaches are used to increase TSP1-mediated inhibition of tumor progression: (1) TSP1-derived peptides, recombinant fragments and mimetics; (2) antibody blockade and gene therapies; (3) upregulation of the potential effects of endogenous TSP1. Numerous peptides and modified structural agents derived from TSP1 have been developed. Here, we only describe some preclinical and clinical drugs, especially those that have been tested in clinical trials (Table 1).

\section{ABT-510}

ABT-510 is the only agent derived from TSP1, which was conducted in phase II clinical trials. It is a 9-amino acid synthetic peptide that has a single D-amino acid replacement in one properdin region heptapeptide. Phase I clinical studies suggested that ABT-510 was safe and well tolerated $[93,94]$. A small phase II study of ABT510 for the treatment of metastatic melanoma did not demonstrate definite clinical efficacy. However, ABT-510 caused significant decrease of peripheral blood VEGF-A and VEGF-C levels. Limited increase in the frequency of peptide specific cytotoxic $\mathrm{T}$ cells was also observed [95]. Phase II study in patients with previously untreated advanced renal cell carcinoma showed little evidence of clinical activity for ABT-510 and further evaluation of ABT-510 as a single agent in renal cell carcinoma was unwarranted [96]. In another phase II study in patients with advanced soft tissue sarcoma, ABT-510 had a favorable safety and tolerability profile.

The rates of disease control and overall survival were encouraging. But the low objective response rate and lack of dose response limited these results as compelling evidence of strong single-agent activity [97]. These responses in clinical trials failed to provide clear evidence of efficacy when used as monotherapy. Importantly, the half life of ABT510 is only one hour in human plasma. ABT-510 is no longer in clinical development. 
Table 1: TSP1-related compounds that have been tested in clinical trials

\begin{tabular}{|l|l|l|l|}
\hline Compound & Origin & Stage & References \\
\hline ABT-510 & TSR1s & Phase II & $92-96$ \\
\hline CVX-045 & TSP1 mimetic+antibody & Phase I & $103-104$ \\
\hline Trabectedin & Marine natural product & Approved & $105-108$ \\
\hline
\end{tabular}

\section{ABT-898}

ABT-898, a second generation of TSP1 mimetic peptide, has enhanced stability, increased half life of 4-5 hours and decreased side effects or toxicities [92]. In a mouse model of human late stage epithelial ovarian cancer and experimental prolactinomas in female rats, ABT-898 induced tumor regression and decreased tumor vasculature $[98,99]$. ABT-898 had more notable antitumor activity compared to ABT-510 in dogs with soft tissue sarcoma [100].

ABT-898 is currently being tested as monotherapy against canine sarcoma. Unfortunately, ABT-898 with sufficiently slow clearance has not been tested in human diseases. Results indicated that ABT-898 was potent in the female reproductive tract, including promoting follicular atresia, inducing ovarian cancer regression, and inhibiting endometriosis in mouse models $[98,101,102]$. In addition, its anti-inflammatory effect in a colitis model may be a new therapeutic alternative in inflammatory diseases [103]. Thus, more clinical trials focused on female reproductive disease and inflammatory diseases are needed in filling in unmet medical needs.

\section{CVX-045}

CVX-045 is a monoclonal antibody fused to TSP1 mimetic peptides, which not only preserves antiangiogenic property but also extends half life. The preclinical data suggested that CVX-045 exhibited significant anti-angiogenic activity in several tumor

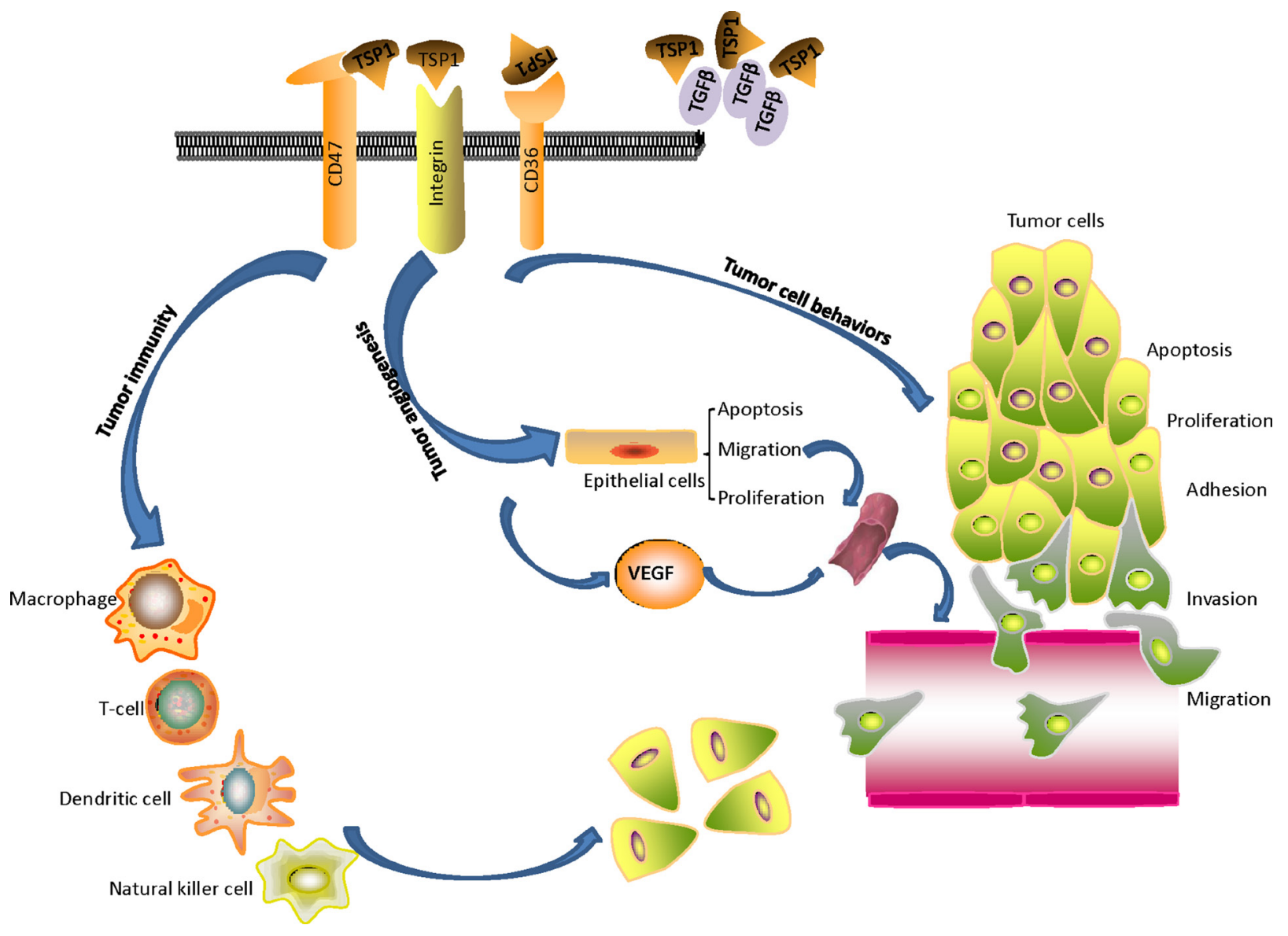

Figure 2: The role of TSP1 on tumor progression: TSP1 binds to multiple membrane proteins, causes direct assembly of complexes, and affects signal transduction that regulates tumor progression. TSP1 acts as an angiogenesis inhibitor by stimulating endothelial cell apoptosis, inhibiting endothelial cell migration and proliferation, and regulating vascular endothelial growth factor bioavailability and activity. TSP1 affects tumor immune response, tumor cell behaviors including adhesion, invasion, migration, apoptosis, and proliferation. 
Table 2: Impact of TSP1 on cancer cell behaviors

\begin{tabular}{|c|c|c|c|c|}
\hline Author & Cancer & TSP1 expression & Impact of TSP1 on cancer cell behaviors & Prognosis \\
\hline $\begin{array}{c}\text { Chandrasekaran } \\
\text { et al. }{ }^{53} \\
\text { Gomes et al. }{ }^{54} \\
\text { John et al. }{ }^{55}\end{array}$ & Breast cancer & - & Pro-adhesive activity & - \\
\hline Albo et al. ${ }^{60}$ & Breast cancer & - & $\begin{array}{l}\text { Promoted invasion } \\
\text { Decreased adhesion }\end{array}$ & - \\
\hline Ndishabandi et al. ${ }^{72}$ & Breast cancer & - & $\begin{array}{l}\text { Promoted tumor growth and decreased } \\
\text { metastasis }\end{array}$ & - \\
\hline Hyder et al. ${ }^{77}$ & Breast cancer & - & $\begin{array}{l}\text { Promoted proliferation (low concentration) } \\
\text { Decreased proliferation (high concentration) }\end{array}$ & - \\
\hline Horiguchi et al. ${ }^{65}$ & $\begin{array}{l}\text { Invasive ductal } \\
\text { carcinoma of the breast }\end{array}$ & $\begin{array}{l}\text { Increased } \\
\text { (IHC) }\end{array}$ & Promoted lymph node metastasis & - \\
\hline Sipes et al. ${ }^{56}$ & Melanoma & - & Pro-adhesive activity & - \\
\hline Borsotti et al. ${ }^{64}$ & Melanoma & $\begin{array}{c}\text { Increased } \\
\text { (microarray analysis) }\end{array}$ & Promoted invasion and metastasis & - \\
\hline Jayachandran et al. ${ }^{66}$ & Melanoma & - & $\begin{array}{l}\text { Promoted invasion, chemoresistance and } \\
\text { mesenchymal phenotypes }\end{array}$ & - \\
\hline Guo et al..$^{57}$ & SCLC & - & Pro-adhesive activity & - \\
\hline Decker et al. ${ }^{58}$ & Osteosarcoma & - & Pro-adhesive activity & - \\
\hline Streit et al. ${ }^{59}$ & $\begin{array}{l}\text { Cutaneous squamous } \\
\text { cell carcinoma }\end{array}$ & - & $\begin{array}{c}\text { Pro-adhesive activity } \\
\text { No effect on proliferation and apoptosis }\end{array}$ & - \\
\hline Pal et al. ${ }^{61}$ & $\begin{array}{l}\text { Oral squamous cell } \\
\text { carcinoma }\end{array}$ & $\begin{array}{c}\text { Increased } \\
\text { (IHC and cDNA } \\
\text { microarray ) }\end{array}$ & Promoted migration and invasion & - \\
\hline Motegi et al. ${ }^{63}$ & Oral tumor & - & Promoted migration & - \\
\hline Seliger et al. ${ }^{62}$ & Glioma & - & Promoted migration & - \\
\hline Firlej et al. ${ }^{67}$ & Prostate cancer & - & Promoted migration and invasion & - \\
\hline Goel et al. ${ }^{78}$ & Prostate cancer & - & No effect on proliferation and apoptosis & - \\
\hline Nucera et al. ${ }^{68}$ & $\begin{array}{l}\text { Papillary } \\
\text { thyroid carcino-ma }\end{array}$ & - & Promoted invasion and metastasis & - \\
\hline Soula-Rothhut et al. ${ }^{69}$ & Thyroid cancer & - & Promoted migration and invasion & - \\
\hline Zhou et al. ${ }^{70}$ & Medulloblasto-ma & - & Promoted migration and invasion & - \\
\hline Huang et al. ${ }^{71}$ & Gastric cancer & $\begin{array}{l}\text { Increased } \\
\text { (IHC) }\end{array}$ & Promoted migration and invasion & - \\
\hline $\begin{array}{l}\text { Bienes-Martinez et } \\
a l_{.}{ }^{73} \\
\end{array}$ & $\begin{array}{c}\text { Clear cell renal } \\
\text { Carcinoma }\end{array}$ & - & Decreased migration and invasion & - \\
\hline Zubac et al..$^{79}$ & $\begin{array}{l}\text { Clear cell renal } \\
\text { Carcinoma }\end{array}$ & $\begin{array}{l}\text { Decreased } \\
\text { (IHC) }\end{array}$ & Decreased proliferation & Survival \\
\hline Tzeng et al. ${ }^{74}$ & $\begin{array}{l}\text { Esophageal squamous } \\
\text { cell carcinoma }\end{array}$ & $\begin{array}{l}\text { Decreased } \\
\text { (IHC) }\end{array}$ & Decreased migration and metastasis & $\begin{array}{l}\text { Progression- } \\
\text { free survival }\end{array}$ \\
\hline Gutierrez et al. ${ }^{75}$ & Intestinal adenoma & - & $\begin{array}{l}\text { Decreased proliferation and promoted } \\
\text { apoptosis }\end{array}$ & - \\
\hline Lopez-Dee et al. ${ }^{76}$ & Colorectal cancer & - & Decreased proliferation & - \\
\hline
\end{tabular}

IHC: The expression of TSP1 was examined by immunohistochemical analysis in cancer tissues.

models and enhanced anti-tumor ability in combination with chemotherapy or targeted therapy [104]. No immunogenicity and dose-limiting toxicities were encountered in phase I results for 18 patients with advanced solid tumors. However, two patients experienced severe adverse events attributed to CVX-045. Only one patient demonstrated partial response and 33\% patients showed stable disease for at least 8 weeks. Limited benefits along with severe adverse events prevent its farther development [105]. 


\section{Trabectedin}

Trabectedin (Yondelis, ET-743), a marine natural product, has been approved for the treatment of advanced or metastatic soft tissue sarcoma and relapsed ovarian cancer. The underlying mechanism remains unclear. Dossi et al. demonstrated that trabectedin showed antiangiogenic activity linked to the upregulation of TSP1, which might represent a potential marker for response to trabectedin [106]. Trabectedin is currently undergoing phase II clinical trials for several other tumors. Trabectedin was well tolerated but lacked activity in pretreated advancedstage colorectal cancer and metastatic pancreatic adenocarcinoma [107, 108]. Single-agent trabectedin had moderate activity in HER2-overexpressing metastatic breast cancer [109]. More clinical trials of trabectedin combined with chemotherapy, radiotherapy or targetedtherapy are needed in the future.

\section{Conclusion and future directions}

The role of TSP1 in tumor progression is summarized in Figure 2 and Table 2. TSP1 binds to multiple membrane proteins, causes direct assembly of complexes, and affects signal transduction that regulates cell proliferation, invasion, migration, apoptosis, differentiation, etc. The correct identification of the TSP1 interaction networks will give us a better understanding of its role and mechanisms of how it acts with interacting molecules to affect biological and pathological processes in cancer.

Therapeutic interventions that either upregulate or downregulate TSP1 may prove useful in the future. Researchers should focus on small molecules that allow a more accurate regulation, thus leading to limited adverse effects and optimal responses. Translation of these small molecules into the clinic and identification of optimal combined strategies with chemotherapy and radiotherapy will be further challenges. Development of innovative therapeutic strategies targeting TSP1 will likely continue for many years and promises to be a fascinating voyage of discovery.

\section{CONFLICTS OF INTEREST}

The authors declare that there is no conflicts of interest.

\section{FUNDING}

This work was supported by the National Natural Science Foundation of China (grants number 81372664).

\section{REFERENCES}

1. Rainero E. Extracellular matrix endocytosis in controlling matrix turnover and beyond: emerging roles in cancer. Biochem Soc Trans. 2016; 44:1347-54. https://doi. org/10.1042/bst20160159.
2. Sid B, Sartelet H, Bellon G, El Btaouri H, Rath G, Delorme N, Haye B, Martiny L. Thrombospondin 1: a multifunctional protein implicated in the regulation of tumor growth. Crit Rev Oncol Hematol. 2004; 49:245-58. https://doi.org/10.1016/j.critrevonc.2003.09.009.

3. Naumov GN, Bender E, Zurakowski D, Kang SY, Sampson D, Flynn E, Watnick RS, Straume O, Akslen LA, Folkman J, Almog N. A model of human tumor dormancy: an angiogenic switch from the nonangiogenic phenotype. J Natl Cancer Inst. 2006; 98:316-25. https://doi.org/10.1093/ jnci/djj068.

4. Jeanne A, Schneider C, Martiny L, Dedieu S. Original insights on thrombospondin-1-related antireceptor strategies in cancer. Front Pharmacol. 2015; 6:252. https://doi. org/10.3389/fphar.2015.00252.

5. Sottile J, Selegue J, Mosher DF. Synthesis of truncated amino-terminal trimers of thrombospondin. Biochemistry. 1991; 30:6556-62.

6. Galvin NJ, Dixit VM, O'Rourke KM, Santoro SA, Grant GA, Frazier WA. Mapping of epitopes for monoclonal antibodies against human platelet thrombospondin with electron microscopy and high sensitivity amino acid sequencing. J Cell Biol. 1985; 101:1434-41.

7. Lawler J, Derick LH, Connolly JE, Chen JH, Chao FC. The structure of human platelet thrombospondin. J Biol Chem. $1985 ; 260: 3762-72$.

8. Dixit VM, Grant GA, Santoro SA, Frazier WA. Isolation and characterization of a heparin-binding domain from the amino terminus of platelet thrombospondin. J Biol Chem. 1984; 259:10100-5.

9. Prochownik EV, O'Rourke K, Dixit VM. Expression and analysis of $\mathrm{COOH}$-terminal deletions of the human thrombospondin molecule. J Cell Biol. 1989; 109:843-52.

10. Lawler JW, Slayter HS, Coligan JE. Isolation and characterization of a high molecular weight glycoprotein from human blood platelets. J Biol Chem. 1978; 253:8609-16.

11. Tolsma SS, Volpert OV, Good DJ, Frazier WA, Polverini PJ, Bouck N. Peptides derived from two separate domains of the matrix protein thrombospondin-1 have anti-angiogenic activity. J Cell Biol. 1993; 122:497-511.

12. Lawler J. The functions of thrombospondin-1 and-2. Curr Opin Cell Biol. 2000; 12:634-40.

13. Lawler J, Weinstein R, Hynes RO. Cell attachment to thrombospondin: the role of ARG-GLY-ASP, calcium, and integrin receptors. J Cell Biol. 1988; 107:2351-61.

14. Lawler J, Duquette M, Urry L, McHenry K, Smith TF. The evolution of the thrombospondin gene family. J Mol Evol. 1993; 36:509-16.

15. Voit S, Udelhoven M, Lill G, Aktas B, Nieswandt B, Schror K, Weber AA. The C-terminal peptide of thrombospondin-1 stimulates distinct signaling pathways but induces an activation-independent agglutination of platelets and other cells. FEBS Lett. 2003; 544:240-5. 
16. Gao AG, Lindberg FP, Finn MB, Blystone SD, Brown EJ, Frazier WA. Integrin-associated protein is a receptor for the C-terminal domain of thrombospondin. J Biol Chem. 1996; 271:21-4.

17. Chen H, Herndon ME, Lawler J. The cell biology of thrombospondin-1. Matrix Biol. 2000; 19:597-614.

18. Sargiannidou I, Qiu C, Tuszynski GP. Mechanisms of thrombospondin-1-mediated metastasis and angiogenesis. Semin Thromb Hemost. 2004; 30:127-36. https://doi. org/10.1055/s-2004-822977.

19. Saaristo A, Karpanen T, Alitalo K. Mechanisms of angiogenesis and their use in the inhibition of tumor growth and metastasis. Oncogene. 2000; 19:6122-9. https://doi. org/10.1038/sj.onc.1203969.

20. Byrne GJ, Hayden KE, McDowell G, Lang H, Kirwan CC, Tetlow L, Kumar S, Bundred NJ. Angiogenic characteristics of circulating and tumoural thrombospondin-1 in breast cancer. Int J Oncol. 2007; 31:1127-32.

21. Dawson DW, Volpert OV, Pearce SF, Schneider AJ, Silverstein RL, Henkin J, Bouck NP. Three distinct D-amino acid substitutions confer potent antiangiogenic activity on an inactive peptide derived from a thrombospondin-1 type 1 repeat. Mol Pharmacol. 1999; 55:332-8.

22. Reiher FK, Volpert OV, Jimenez B, Crawford SE, Dinney CP, Henkin J, Haviv F, Bouck NP, Campbell SC. Inhibition of tumor growth by systemic treatment with thrombospondin-1 peptide mimetics. Int J Cancer. 2002; 98:682-9.

23. Iruela-Arispe ML, Lombardo M, Krutzsch HC, Lawler J, Roberts DD. Inhibition of angiogenesis by thrombospondin-1 is mediated by 2 independent regions within the type 1 repeats. Circulation. 1999; 100:1423-31.

24. Miyata Y, Koga S, Takehara K, Kanetake H, Kanda S. Expression of thrombospondin-derived $4 \mathrm{~N} 1 \mathrm{~K}$ peptidecontaining proteins in renal cell carcinoma tissues is associated with a decrease in tumor growth and angiogenesis. Clin Cancer Res. 2003; 9:1734-40.

25. Miyata $\mathrm{Y}$, Watanabe $\mathrm{S}$, Kanetake $\mathrm{H}$, Sakai $\mathrm{H}$. Thrombospondin-1-derived $4 \mathrm{~N} 1 \mathrm{~K}$ peptide expression is negatively associated with malignant aggressiveness and prognosis in urothelial carcinoma of the upper urinary tract. BMC Cancer. 2012; 12:372. https://doi.org/10.1186/14712407-12-372.

26. Taraboletti G, Morbidelli L, Donnini S, Parenti A, Granger HJ, Giavazzi R, Ziche M. The heparin binding 25 $\mathrm{kDa}$ fragment of thrombospondin-1 promotes angiogenesis and modulates gelatinase and TIMP-2 production in endothelial cells. Faseb j. 2000; 14:1674-6. https://doi. org/10.1096/fj.99-0931fje.

27. Ferrari do Outeiro-Bernstein MA, Nunes SS, Andrade AC, Alves TR, Legrand C, Morandi V. A recombinant $\mathrm{NH}(2)$-terminal heparin-binding domain of the adhesive glycoprotein, thrombospondin-1, promotes endothelial tube formation and cell survival: a possible role for syndecan-4 proteoglycan. Matrix Biol. 2002; 21:311-24.
28. Guo N, Krutzsch HC, Inman JK, Roberts DD. Thrombospondin 1 and type I repeat peptides of thrombospondin 1 specifically induce apoptosis of endothelial cells. Cancer Res. 1997; 57:1735-42.

29. Silverstein RL, Febbraio M. CD36, a scavenger receptor involved in immunity, metabolism, angiogenesis, and behavior. Sci Signal. 2009; 2:re3. https://doi.org/10.1126/ scisignal.272re3.

30. Dawson DW, Pearce SF, Zhong R, Silverstein RL, Frazier WA, Bouck NP. CD36 mediates the In vitro inhibitory effects of thrombospondin-1 on endothelial cells. J Cell Biol. 1997; 138:707-17.

31. Jimenez B, Volpert OV, Crawford SE, Febbraio M, Silverstein RL, Bouck N. Signals leading to apoptosisdependent inhibition of neovascularization by thrombospondin-1. Nat Med. 2000; 6:41-8. https://doi. org/10.1038/71517.

32. Volpert OV, Zaichuk T, Zhou W, Reiher F, Ferguson TA, Stuart PM, Amin M, Bouck NP. Inducer-stimulated Fas targets activated endothelium for destruction by antiangiogenic thrombospondin-1 and pigment epitheliumderived factor. Nat Med. 2002; 8:349-57. https://doi. org/10.1038/nm0402-349.

33. Jimenez B, Volpert OV, Reiher F, Chang L, Munoz A, Karin M, Bouck N. c-Jun N-terminal kinase activation is required for the inhibition of neovascularization by thrombospondin-1. Oncogene. 2001; 20:3443-8. https:// doi.org/10.1038/sj.onc.1204464.

34. Freyberg MA, Kaiser D, Graf R, Vischer P, Friedl P. Integrin-associated protein and thrombospondin-1 as endothelial mechanosensitive death mediators. Biochem Biophys Res Commun. 2000; 271:584-8. https://doi. org/10.1006/bbrc.2000.2678.

35. Freyberg MA, Kaiser D, Graf R, Buttenbender J, Friedl P. Proatherogenic flow conditions initiate endothelial apoptosis via thrombospondin-1 and the integrin-associated protein. Biochem Biophys Res Commun. 2001; 286:141-9. https://doi.org/10.1006/bbrc.2001.5314.

36. Stromblad S, Becker JC, Yebra M, Brooks PC, Cheresh DA. Suppression of $\mathrm{p} 53$ activity and p21WAF1/CIP1 expression by vascular cell integrin alphaVbeta3 during angiogenesis. J Clin Invest. 1996; 98:426-33. https://doi.org/10.1172/ jci118808.

37. Chan LY, Craik DJ, Daly NL. Cyclic thrombospondin-1 mimetics: grafting of a thrombospondin sequence into circular disulfide-rich frameworks to inhibit endothelial cell migration. Biosci Rep. 2015; 35. https://doi.org/10.1042/ bsr20150210.

38. Short SM, Derrien A, Narsimhan RP, Lawler J, Ingber DE, Zetter BR. Inhibition of endothelial cell migration by thrombospondin-1 type-1 repeats is mediated by beta 1 integrins. J Cell Biol. 2005; 168:643-53. https://doi. org/10.1083/jcb.200407060.

39. Calzada MJ, Annis DS, Zeng B, Marcinkiewicz C, Banas B, Lawler J, Mosher DF, Roberts DD. Identification of novel 
beta 1 integrin binding sites in the type 1 and type 2 repeats of thrombospondin-1. J Biol Chem. 2004; 279:41734-43. https://doi.org/10.1074/jbc.M406267200.

40. Yamauchi M, Imajoh-Ohmi S, Shibuya M. Novel antiangiogenic pathway of thrombospondin-1 mediated by suppression of the cell cycle. Cancer Sci. 2007; 98:1491-7. https://doi.org/10.1111/j.1349-7006.2007.00534.x.

41. Oganesian A, Armstrong LC, Migliorini MM, Strickland DK, Bornstein P. Thrombospondins use the VLDL receptor and a nonapoptotic pathway to inhibit cell division in microvascular endothelial cells. Mol Biol Cell. 2008; 19:563-71. https://doi.org/10.1091/mbc.E07-07-0649.

42. Dvorak HF, Brown LF, Detmar M, Dvorak AM. Vascular permeability factor/vascular endothelial growth factor, microvascular hyperpermeability, and angiogenesis. Am J Pathol. 1995; 146:1029-39.

43. Kawahara N, Ono M, Taguchi K, Okamoto M, Shimada M, Takenaka K, Hayashi K, Mosher DF, Sugimachi K, Tsuneyoshi M, Kuwano M. Enhanced expression of thrombospondin-1 and hypovascularity in human cholangiocarcinoma. Hepatology. 1998; 28:1512-7. https:// doi.org/10.1002/hep.510280610.

44. de Fraipont F, El Atifi M, Gicquel C, Bertagna X, Chambaz EM, Feige JJ. Expression of the angiogenesis markers vascular endothelial growth factor-A, thrombospondin-1, and platelet-derived endothelial cell growth factor in human sporadic adrenocortical tumors: correlation with genotypic alterations. J Clin Endocrinol Metab. 2000; 85:4734 41. https://doi.org/10.1210/jcem.85.12.7012.

45. Tanaka K, Sonoo H, Kurebayashi J, Nomura T, Ohkubo S, Yamamoto Y, Yamamoto S. Inhibition of infiltration and angiogenesis by thrombospondin-1 in papillary thyroid carcinoma. Clin Cancer Res. 2002; 8:1125-31.

46. Sarkar AJ, Chaturvedi K, Chen CP, Sarkar DK. Changes in thrombospondin-1 levels in the endothelial cells of the anterior pituitary during estrogen-induced prolactinsecreting pituitary tumors. J Endocrinol. 2007; 192:395403. https://doi.org/10.1677/joe.1.06925.

47. Fontana A, Filleur S, Guglielmi J, Frappart L, BrunoBossio G, Boissier S, Cabon F, Clezardin P. Human breast tumors override the antiangiogenic effect of stromal thrombospondin-1 in vivo. Int J Cancer. 2005; 116:686-91. https://doi.org/10.1002/ijc.20584.

48. Mukhopadhyay D, Tsiokas L, Sukhatme VP. Wild-type p53 and v-Src exert opposing influences on human vascular endothelial growth factor gene expression. Cancer Res. 1995; 55:6161-5.

49. Grossfeld GD, Ginsberg DA, Stein JP, Bochner BH, Esrig D, Groshen S, Dunn M, Nichols PW, Taylor CR, Skinner DG, Cote RJ. Thrombospondin-1 expression in bladder cancer: association with p53 alterations, tumor angiogenesis, and tumor progression. J Natl Cancer Inst. 1997; 89:219-27.

50. Dameron KM, Volpert OV, Tainsky MA, Bouck N. Control of angiogenesis in fibroblasts by $\mathrm{p} 53$ regulation of thrombospondin-1. Science. 1994; 265:1582-4.
51. Fontanini G, Boldrini L, Calcinai A, Chine S, Lucchi M, Mussi A, Angeletti CA, Basolo F, Bevilacqua G. Thrombospondins I and II messenger RNA expression in lung carcinoma: relationship with $\mathrm{p} 53$ alterations, angiogenic growth factors, and vascular density. Clin Cancer Res. 1999; 5:155-61.

52. Tuszynski GP, Rothman V, Murphy A, Siegler K, Smith L, Smith S, Karczewski J, Knudsen KA. Thrombospondin promotes cell-substratum adhesion. Science. 1987; 236:1570-3.

53. Chandrasekaran S, Guo NH, Rodrigues RG, Kaiser J, Roberts DD. Pro-adhesive and chemotactic activities of thrombospondin-1 for breast carcinoma cells are mediated by alpha3betal integrin and regulated by insulin-like growth factor-1 and CD98. J Biol Chem. 1999; 274:11408-16.

54. Gomes N, Legrand C, Fauvel-Lafeve F. Shear stress induced release of von Willebrand factor and thrombospondin-1 in HUVEC extracellular matrix enhances breast tumour cell adhesion. Clin Exp Metastasis. 2005; 22:215-23. https:// doi.org/10.1007/s10585-005-7359-5.

55. John AS, Rothman VL, Tuszynski GP. Thrombospondin-1 (TSP-1) Stimulates Expression of Integrin alpha6 in Human Breast Carcinoma Cells: A Downstream Modulator of TSP1-Induced Cellular Adhesion. J Oncol. 2010; 2010:645376. https://doi.org/10.1155/2010/645376.

56. Sipes JM, Krutzsch HC, Lawler J, Roberts DD. Cooperation between thrombospondin-1 type 1 repeat peptides and alpha(v)beta(3) integrin ligands to promote melanoma cell spreading and focal adhesion kinase phosphorylation. J Biol Chem. 1999; 274:22755-62.

57. Guo N, Templeton NS, Al-Barazi H, Cashel JA, Sipes JM, Krutzsch HC, Roberts DD. Thrombospondin-1 promotes alpha3beta1 integrin-mediated adhesion and neurite-like outgrowth and inhibits proliferation of small cell lung carcinoma cells. Cancer Res. 2000; 60:457-66.

58. Decker S, van Valen F, Vischer P. Adhesion of osteosarcoma cells to the $70-\mathrm{kDa}$ core region of thrombospondin-1 is mediated by the alpha 4 beta 1 integrin. Biochem Biophys Res Commun. 2002; 293:86-92. https://doi.org/10.1016/ s0006-291x(02)00180-8.

59. Streit M, Velasco P, Brown LF, Skobe M, Richard L, Riccardi L, Lawler J, Detmar M. Overexpression of thrombospondin-1 decreases angiogenesis and inhibits the growth of human cutaneous squamous cell carcinomas. Am J Pathol. 1999; 155:441-52. https://doi.org/10.1016/s00029440(10)65140-1.

60. Albo D, Rothman VL, Roberts DD, Tuszynski GP. Tumour cell thrombospondin-1 regulates tumour cell adhesion and invasion through the urokinase plasminogen activator receptor. Br J Cancer. 2000; 83:298-306. https://doi. org/10.1054/bjoc.2000.1268.

61. Pal SK, Nguyen CT, Morita KI, Miki Y, Kayamori K, Yamaguchi A, Sakamoto K. THBS1 is induced by TGFB1 in the cancer stroma and promotes invasion of oral squamous cell carcinoma. J Oral Pathol Med. 2016; 45:730-9. https://doi.org/10.1111/jop.12430. 
62. Seliger C, Leukel P, Moeckel S, Jachnik B, Lottaz C, Kreutz M, Brawanski A, Proescholdt M, Bogdahn U, Bosserhoff AK, Vollmann-Zwerenz A, Hau P. Lactatemodulated induction of THBS-1 activates transforming growth factor (TGF)-beta2 and migration of glioma cells in vitro. PLoS One. 2013; 8:e78935. https://doi.org/10.1371/ journal.pone.0078935.

63. Motegi K, Harada K, Ohe G, Jones SJ, Ellis IR, Crouch DH, Schor SL, Schor AM. Differential involvement of TGFbeta1 in mediating the motogenic effects of TSP-1 on endothelial cells, fibroblasts and oral tumour cells. Exp Cell Res. 2008; 314:2323-33. https://doi.org/10.1016/j. yexcr.2008.04.013.

64. Borsotti P, Ghilardi C, Ostano P, Silini A, Dossi R, Pinessi D, Foglieni C, Scatolini M, Lacal PM, Ferrari R, Moscatelli D, Sangalli F, D’Atri S, et al. Thrombospondin-1 is part of a Slug-independent motility and metastatic program in cutaneous melanoma, in association with VEGFR-1 and FGF-2. Pigment Cell Melanoma Res. 2015; 28:73-81. https://doi.org/10.1111/pcmr.12319.

65. Horiguchi H, Yamagata S, Rong Qian Z, Kagawa S, Sakashita N. Thrombospondin-1 is highly expressed in desmoplastic components of invasive ductal carcinoma of the breast and associated with lymph node metastasis. J Med Invest. 2013; 60:91-6.

66. Jayachandran A, Anaka M, Prithviraj P, Hudson C, McKeown SJ, Lo PH, Vella LJ, Goding CR, Cebon J, Behren A. Thrombospondin 1 promotes an aggressive phenotype through epithelial-to-mesenchymal transition in human melanoma. Oncotarget. 2014; 5:5782-97. https:// doi.org/10.18632/oncotarget.2164.

67. Firlej V, Mathieu JR, Gilbert C, Lemonnier L, Nakhle J, Gallou-Kabani C, Guarmit B, Morin A, Prevarskaya N, Delongchamps NB, Cabon F. Thrombospondin-1 triggers cell migration and development of advanced prostate tumors. Cancer Res. 2011; 71:7649-58. https://doi. org/10.1158/0008-5472.can-11-0833.

68. Nucera C, Porrello A, Antonello ZA, Mekel M, Nehs MA, Giordano TJ, Gerald D, Benjamin LE, Priolo C, Puxeddu E, Finn S, Jarzab B, Hodin RA, et al. B-Raf(V600E) and thrombospondin-1 promote thyroid cancer progression. Proc Natl Acad Sci USA. 2010; 107:10649-54. https://doi. org/10.1073/pnas.1004934107.

69. Soula-Rothhut M, Coissard C, Sartelet H, Boudot C, Bellon G, Martiny L, Rothhut B. The tumor suppressor PTEN inhibits EGF-induced TSP-1 and TIMP-1 expression in FTC-133 thyroid carcinoma cells. Exp Cell Res. 2005; 304:187-201. https://doi.org/10.1016/j.yexcr.2004.10.026.

70. Zhou L, Picard D, Ra YS, Li M, Northcott PA, Hu Y, Stearns D, Hawkins C, Taylor MD, Rutka J, Der SD, Huang A. Silencing of thrombospondin-1 is critical for mycinduced metastatic phenotypes in medulloblastoma. Cancer Res. 2010; 70:8199-210. https://doi.org/10.1158/00085472.can-09-4562.
71. Huang T, Wang L, Liu D, Li P, Xiong H, Zhuang L, Sun L, Yuan X, Qiu H. FGF7/FGFR2 signal promotes invasion and migration in human gastric cancer through upregulation of thrombospondin-1. Int J Oncol. 2017; 50:1501-12. https:// doi.org/10.3892/ijo.2017.3927.

72. Ndishabandi D, Duquette C, Billah GE, Reyes M, Duquette M, Lawler J, Kazerounian S. Thrombospondin-1 Modulates Actin Filament Remodeling and Cell Motility in Mouse Mammary Tumor cells in Vitro. Discoveries (Craiova). 2014; 2. https://doi.org/10.15190/d.2014.23.

73. Bienes-Martinez R, Ordonez A, Feijoo-Cuaresma M, Corral-Escariz M, Mateo G, Stenina O, Jimenez B, Calzada MJ. Autocrine stimulation of clear-cell renal carcinoma cell migration in hypoxia via HIF-independent suppression of thrombospondin-1. Sci Rep. 2012; 2:788. https://doi.org/10.1038/srep00788.

74. Tzeng HT, Tsai CH, Yen YT, Cheng HC, Chen YC, Pu SW, Wang YS, Shan YS, Tseng YL, Su WC, Lai WW, Wu LW, Wang YC. Dysregulation of Rab37-Mediated Crosstalk between Cancer Cells and Endothelial Cells via Thrombospondin-1 Promotes Tumor Neovasculature and Metastasis. Clin Cancer Res. 2017; 23:2335-45. https://doi. org/10.1158/1078-0432.ccr-16-1520.

75. Gutierrez LS, Suckow M, Lawler J, Ploplis VA, Castellino FJ. Thrombospondin 1-a regulator of adenoma growth and carcinoma progression in the APC(Min/+) mouse model. Carcinogenesis. 2003; 24:199-207.

76. Lopez-Dee ZP, Chittur SV, Patel H, Chinikaylo A, Lippert B, Patel B, Lawler J, Gutierrez LS. Thrombospondin-1 in a Murine Model of Colorectal Carcinogenesis. PLoS One. 2015; 10:e0139918. https://doi.org/10.1371/journal. pone. 0139918 .

77. Hyder SM, Liang Y, Wu J. Estrogen regulation of thrombospondin-1 in human breast cancer cells. Int J Cancer. 2009; 125:1045-53. https://doi.org/10.1002/ijc.24373.

78. Goel HL, Moro L, Murphy-Ullrich JE, Hsieh CC, Wu CL, Jiang Z, Languino LR. Betal integrin cytoplasmic variants differentially regulate expression of the antiangiogenic extracellular matrix protein thrombospondin 1. Cancer Res. 2009; 69:5374-82. https://doi.org/10.1158/0008-5472.can09-0186.

79. Zubac DP, Bostad L, Kihl B, Seidal T, Wentzel-Larsen T, Haukaas SA. The expression of thrombospondin-1 and p53 in clear cell renal cell carcinoma: its relationship to angiogenesis, cell proliferation and cancer specific survival. J Urol. 2009; 182:2144-9. https://doi. org/10.1016/j.juro.2009.07.015.

80. Pandya PH, Murray ME, Pollok KE, Renbarger JL. The Immune System in Cancer Pathogenesis: Potential Therapeutic Approaches. 2016; 2016:4273943. https://doi. org/10.1155/2016/4273943.

81. Riser BL, Mitra R, Perry D, Dixit V, Varani J. Monocyte killing of human squamous epithelial cells: role for thrombospondin. Cancer Res. 1989; 49:6123-9. 
82. Martin-Manso G, Galli S, Ridnour LA, Tsokos M, Wink DA, Roberts DD. Thrombospondin 1 promotes tumor macrophage recruitment and enhances tumor cell cytotoxicity of differentiated U937 cells. Cancer Res. 2008; 68:7090-9. https://doi.org/10.1158/0008-5472.can-08-0643.

83. Kirsch T, Woywodt A, Klose J, Wyss K, Beese M, Erdbruegger U, Grossheim M, Haller H, Haubitz M. Endothelial-derived thrombospondin-1 promotes macrophage recruitment and apoptotic cell clearance. J Cell Mol Med. 2010; 14:1922-34. https://doi.org/10.1111/ j.1582-4934.2009.00799.x.

84. Fang LL, Yu HQ, Wu RJ, He C, Li M, Yan H, Li JJ, Wang S, Liu ZG, Liu ZJ, Yang PC. Thrombospondin 1 Modulates Monocyte Properties to Suppress Intestinal Mucosal Inflammation. J Innate Immun. 2015; 7:601-11. https://doi. org/10.1159/000398799.

85. Pierson BA, Gupta K, Hu WS, Miller JS. Human natural killer cell expansion is regulated by thrombospondinmediated activation of transforming growth factor-beta 1 and independent accessory cell-derived contact and soluble factors. Blood. 1996; 87:180-9.

86. Kudo-Saito C, Shirako H, Takeuchi T, Kawakami Y. Cancer metastasis is accelerated through immunosuppression during Snail-induced EMT of cancer cells. Cancer Cell. 2009; 15:195-206. https://doi.org/10.1016/j. ccr.2009.01.023.

87. Miller TW, Kaur S, Ivins-O'Keefe K, Roberts DD. Thrombospondin-1 is a CD47-dependent endogenous inhibitor of hydrogen sulfide signaling in T cell activation. Matrix Biol. 2013; 32:316-24. https://doi.org/10.1016/j. matbio.2013.02.009.

88. Van VQ, Lesage S, Bouguermouh S, Gautier P, Rubio M, Levesque M, Nguyen S, Galibert L, Sarfati M. Expression of the self-marker CD47 on dendritic cells governs their trafficking to secondary lymphoid organs. Embo j. 2006; 25:5560-8. https://doi.org/10.1038/sj.emboj.7601415.

89. Doyen V, Rubio M, Braun D, Nakajima T, Abe J, Saito H, Delespesse G, Sarfati M. Thrombospondin 1 is an autocrine negative regulator of human dendritic cell activation. J Exp Med. 2003; 198:1277-83. https://doi. org/10.1084/jem.20030705.

90. Bandyopadhyay G, Bandyopadhyay S, Bankey PE, Miller-Graziano CL. Elevated postinjury thrombospondin 1-CD47 triggering aids differentiation of patients' defective inflammatory CD1a+dendritic cells. J Leukoc Biol. 2014; 96:797-807. https://doi.org/10.1189/jlb.4MA0214-077R.

91. Weng TY, Huang SS, Yen MC, Lin CC, Chen YL, Lin CM, Chen WC, Wang CY, Chang JY, Lai MD. A novel cancer therapeutic using thrombospondin 1 in dendritic cells. Mol Ther. 2014; 22:292-302. https://doi.org/10.1038/ mt.2013.236.

92. Henkin J, Volpert OV. Therapies using anti-angiogenic peptide mimetics of thrombospondin-1. Expert Opin Ther Targets. 2011; 15:1369-86. https://doi.org/10.1517/147282 22.2011.640319.
93. Hoekstra R, de Vos FY, Eskens FA, Gietema JA, van der Gaast A, Groen HJ, Knight RA, Carr RA, Humerickhouse RA, Verweij J, de Vries EG. Phase I safety, pharmacokinetic, and pharmacodynamic study of the thrombospondin-1-mimetic angiogenesis inhibitor ABT510 in patients with advanced cancer. J Clin Oncol. 2005; 23:5188-97. https://doi.org/10.1200/jco.2005.05.013.

94. Hoekstra R, de Vos FY, Eskens FA, de Vries EG, Uges DR, Knight R, Carr RA, Humerickhouse R, Verweij J, Gietema JA. Phase I study of the thrombospondin-1mimetic angiogenesis inhibitor ABT-510 with 5-fluorouracil and leucovorin: a safe combination. Eur J Cancer. 2006; 42:467-72. https://doi.org/10.1016/j.ejca.2005.08.040.

95. Markovic SN, Suman VJ, Rao RA, Ingle JN, Kaur JS, Erickson LA, Pitot HC, Croghan GA, McWilliams RR, Merchan J, Kottschade LA, Nevala WK, Uhl CB, et al. A phase II study of ABT-510 (thrombospondin-1 analog) for the treatment of metastatic melanoma. Am J Clin Oncol. 2007; 30:303-9. https://doi.org/10.1097/01. coc.0000256104.80089.35.

96. Ebbinghaus S, Hussain M, Tannir N, Gordon M, Desai AA, Knight RA, Humerickhouse RA, Qian J, Gordon GB, Figlin R. Phase 2 study of ABT-510 in patients with previously untreated advanced renal cell carcinoma. Clin Cancer Res. 2007; 13:6689-95. https://doi. org/10.1158/1078-0432.ccr-07-1477.

97. Baker LH, Rowinsky EK, Mendelson D, Humerickhouse RA, Knight RA, Qian J, Carr RA, Gordon GB, Demetri GD. Randomized, phase II study of the thrombospondin-1mimetic angiogenesis inhibitor ABT-510 in patients with advanced soft tissue sarcoma. J Clin Oncol. 2008; 26:55838. https://doi.org/10.1200/jco.2008.17.4706.

98. Campbell N, Greenaway J, Henkin J, Petrik J. ABT-898 induces tumor regression and prolongs survival in a mouse model of epithelial ovarian cancer. Mol Cancer Ther. 2011; 10:1876-85. https://doi.org/10.1158/1535-7163.mct-11-0402.

99. Recouvreux MV, Camilletti MA, Rifkin DB, BecuVillalobos D, Diaz-Torga G. Thrombospondin-1 (TSP-1) analogs ABT-510 and ABT-898 inhibit prolactinoma growth and recover active pituitary transforming growth factorbeta1 (TGF-beta1). Endocrinology. 2012; 153:3861-71. https://doi.org/10.1210/en.2012-1007.

100. Sahora AI, Rusk AW, Henkin J, McKeegan EM, Shi Y, Khanna C. Prospective study of thrombospondin-1 mimetic peptides, ABT-510 and ABT-898, in dogs with soft tissue sarcoma. J Vet Intern Med. 2012; 26:1169-76. https://doi. org/10.1111/j.1939-1676.2012.00966.x.

101. Nakamura DS, Edwards AK, Ahn SH, Thomas R, Tayade C. Compatibility of a novel thrombospondin-1 analog with fertility and pregnancy in a xenograft mouse model of endometriosis. PLoS One. 2015; 10:e0121545. https://doi. org/10.1371/journal.pone.0121545.

102. Garside SA, Henkin J, Morris KD, Norvell SM, Thomas FH, Fraser HM. A thrombospondin-mimetic peptide, ABT-898, suppresses angiogenesis and promotes follicular atresia in 
pre- and early-antral follicles in vivo. Endocrinology. 2010; 151:5905-15. https://doi.org/10.1210/en.2010-0283.

103. Gutierrez LS, Ling J, Nye D, Papathomas K, Dickinson C. Thrombospondin peptide ABT-898 inhibits inflammation and angiogenesis in a colitis model. World J Gastroenterol. 2015; 21:6157-66. https://doi.org/10.3748/wjg.v21. i20.6157.

104. Li L, Leedom TA, Do J, Huang H, Lai J, Johnson K, Osothprarop TF, Rizzo JD, Doppalapudi VR, Bradshaw CW, Lappe RW, Woodnutt G, Levin NJ, et al. Antitumor efficacy of a thrombospondin 1 mimetic CovX-body. Transl Oncol. 2011; 4:249-57.

105. Molckovsky A, Siu LL. First-in-class, first-in-human phase I results of targeted agents: highlights of the 2008 American society of clinical oncology meeting. J Hematol Oncol. 2008; 1:20. https://doi.org/10.1186/1756-8722-1-20.

106. Dossi R, Frapolli R, Di Giandomenico S, Paracchini L, Bozzi F, Brich S, Castiglioni V, Borsotti P, Belotti D, Uboldi S, Sanfilippo R, Erba E, Giavazzi R, et al. Antiangiogenic activity of trabectedin in myxoid liposarcoma: involvement of host TIMP-1 and TIMP-2 and tumor thrombospondin-1. Int J Cancer. 2015; 136:721-9. https://doi.org/10.1002/ijc.29023.
107. Paz-Ares L, Rivera-Herreros F, Diaz-Rubio E, Garcia M, Casado E, Cubedo R, Gravalos C, Alfaro V, Gomez J, Izquierdo MA, Tabernero J. Phase II study of trabectedin in pretreated patients with advanced colorectal cancer. Clin Colorectal Cancer. 2007; 6:522-8. https://doi.org/10.3816/ CCC.2007.n.018.

108. Belli C, Piemonti L, D’Incalci M, Zucchetti M, Porcu L, Cappio S, Doglioni C, Allavena P, Ceraulo D, Maggiora P, Dugnani E, Cangi MG, Garassini G, et al. Phase II trial of salvage therapy with trabectedin in metastatic pancreatic adenocarcinoma. Cancer Chemother Pharmacol. 2016; 77:477-84. https://doi.org/10.1007/s00280-015-2932-3.

109. Blum JL, Goncalves A, Efrat N, Debled M, Conte P, Richards PD, Richards D, Lardelli P, Nieto A, CullellYoung M, Delaloge S. A phase II trial of trabectedin in triple-negative and HER2-overexpressing metastatic breast cancer. Breast Cancer Res Treat. 2016; 155:295-302. https://doi.org/10.1007/s10549-015-3675-x. 